\title{
New species of Prostanthera section Prostanthera (Labiatae) from New South Wales
}

\author{
Barry J. Conn
}

National Herbarium of New South Wales, Mrs Macquaries Road, Sydney 2000, Australia

\begin{abstract}
Prostanthera petraea and P. stenophylla are described for the first time. Although these species have very restricted distributions, they are regarded as adequately protected because they both occur within National Parks.
\end{abstract}

\section{Introduction}

The two species of Prostanthera that are formally named in this paper have been well known for a long time. Prostanthera petraea appears to have first been collected by J.F. Thomas from Boonoo Boonoo during July 1936, whereas Prostanthera stenophylla was first recognized as a possible undescribed species when it was collected by George W. Althofer in 1952 from an area that has since become part of the Wollemi National Park. An earlier collection by Lindsay D. Pryor (December 1937) from the Canberra district also appears to be this latter species. Subsequently, P. stenophylla, under the unpublished name 'Prostanthera rylstonii', has been promoted as a suitable Australian species for horticulture and is now occasionally grown in gardens.

An identification guide (key) to these species, under their unpublished informal names, is included in Conn (1992). Terminology follows Conn (1984), except inflorescence terminology, particularly podial features (replacing the more typical terminology of 'pedicel'), are based on Conn (1995).

\section{Taxonomy}

Prostanthera petraea B.J.Conn, sp. nov.

P. lasiantho Labill. affinis, a qua inflorescentiis botryoidalibus, foliis olivaceis integris differt.

Holotype: New South Wales: Northern Tablelands: Bald Rock National Park: Bungoona Walking Track, B.J. Conn 3668 \& E.A. Brown, 11 Oct 1992, (NSW 260615); isotypes: BRI, CANB, K, MEL.

Prostanthera species B sensu Conn, in Harden (ed.) Flora of New South Wales, vol. 3: 656 and fig. (1992); PlantNET (http://plantnet.rbgsyd.nsw.gov.au) (accessed March 2006) as 'Prostanthera sp. B sensu Conn (1992)' and Prostanthera sp. 'Boonoo Boonoo' (T.D. Stanley 78/76). 
Shrub to small tree, 1-3(-5) $\mathrm{m}$ high, branching from up to $1 \mathrm{~m}$ above base. Branches laterally 2-ridged or on older branches becoming more equally spaced 4-ridged, moderately to densely hairy $\left(20-40\right.$ hairs $\left./ \mathrm{mm}^{2}\right)$, mostly restricted to ridges and area between ridges; hairs \pm curved, antrorse, sub-appressed, 0.5-1 mm long, white, moderately glandular (10-20 hairs $\left./ \mathrm{mm}^{2}\right)$; glands hemispherical. Leaves dull, olivegreen above, much paler below, faintly but pleasantly aromatic when crushed.; petiole (5-)7-12 mm long, hairy at base; lamina ovate, (25-)35-50(-70) $\mathrm{mm}$ long, (12-) 15-25(-27) mm wide (length to width ratio (1.9-)2-2.6, length of maximum width from base to total lamina length ratio $0.4-0.5)$, glabrous, distinctly and moderately glandular (10-15 hairs $\left./ \mathrm{mm}^{2}\right)$; base attenuate and shortly decurrent; margin entire, slightly recurved; apex obtuse to sub-acuminate; venation indistinct or not visible, midrib slightly raised basally. Inflorescence a frondose (at base) dibotryoid conflorescence, uniflorescence botryoid; 5-13-flowered (per uniflorescence, up to c. 30-flowered per conflorescence). Podium 1-2 mm long, glabrous or with an occasional hair, densely glandular. Prophylls not persistent, usually only base persisting, inserted just below calyx ( $a_{1}$ axis to anthopodium ratio 10-20), opposite, narrowly elliptic, 2.5-3 mm long, $0.2-0.3 \mathrm{~mm}$ wide (length to width ratio $1-1.3$, length of maximum width from base to total lamina length ratio c. 0.5), glabrous or with an occasional hair, densely glandular; base attenuate; margin entire; apex attenuate; venation not visible. Calyx light green; outer surface glabrous, moderately glandular; inner surface glabrous, except margin shortly fimbriate; tube $4.5-5 \mathrm{~mm}$ long; abaxial lobe broadly to very broadly ovate, $3.5-4 \mathrm{~mm}$ long, $3.5-5 \mathrm{~mm}$ wide at base (length to width ratio $0.8-1.2$ ), apex rounded, slightly irregular, often slightly retuse; adaxial lobe transversely ovate, $2.5-3.3 \mathrm{~mm}$ long, $4.4-5 \mathrm{~mm}$ wide at base (length to width ratio $0.5-0.7$ ), apex obtuse to rounded (adaxial lobe length to abaxial lobe length ratio 0.7-0.8). Corolla 8-12 mm long, white, lacking markings, once recorded with pale mauve dots in throat (Jobson 5225); outer surface glabrous, sparsely glandular; inner surface glabrous in tube and distally on lobes, sparsely hairy $\left(6-12\right.$ hairs $\left./ \mathrm{mm}^{2}\right)$ near base of lobes, especially near sinus between adaxial and abaxial lobes; tube 5-6 mm long; abaxial median lobes spathulate, 5.5-7 $\mathrm{mm}$ long, 4.5-5.5 $\mathrm{mm}$ wide (length to width ratio $0.8-1.3$ ), apex irregular and rounded, usually bilobed (sinus c. $1 \mathrm{~mm}$ long, $1-1.5 \mathrm{~mm}$ wide distally); lateral lobes elliptic, 5-6 mm long, 3-3.5 mm wide (length to width ratio 1.6-1.7), apex slightly irregular, rounded to slightly retuse; adaxial median lobe-pair depressed ovate to very depressed ovate, $4-5 \mathrm{~mm}$ long, $10-12 \mathrm{~mm}$ wide (length to width ratio c. 0.6 ), apex rounded, irregular, bilobed (sinus $2-4 \mathrm{~mm}$ long, median margin of lobes usually overlapping). Stamens inserted 1.5-2 mm above base of corolla; filaments 4-5 mm long; anthers 1.3-1.5 mm long, lobes slightly cristate on basal dorsal surface (narrowly triangular trichomes $0.1-0.2 \mathrm{~mm}$ long) with small acumen basally, connective extended to form a basal appendage $0.5-0.8 \mathrm{~mm}$ long, terminating in a few (up to c. 6) narrowly triangular trichomes $0.1-0.2 \mathrm{~mm}$ long. Disc 0.4-0.6 mm long. Pistil 8-9 mm long; ovary cylindrical obovoid, $0.4-0.5 \mathrm{~mm}$ long, diameter at base $0.5-0.6 \mathrm{~mm}$, lobes 0.1-0.2 mm long; style c. $4 \mathrm{~mm}$ long; stigma lobes $0.6-0.8 \mathrm{~mm}$ long. Fruiting calyx not or only slightly enlarged Mericarps $1.3-2 \mathrm{~mm}$ long, distally $0.5-1 \mathrm{~mm}$ extended beyond base of style, distal diameter $2.3-2.6 \mathrm{~mm}$; seeds ellipsoid-cylindrical to slightly obovoid, c.1 mm long, 0.6-1 mm diameter (slightly flattened). Figure 1.

Flowering: late Spring - early Summer. Fruiting: Summer. 


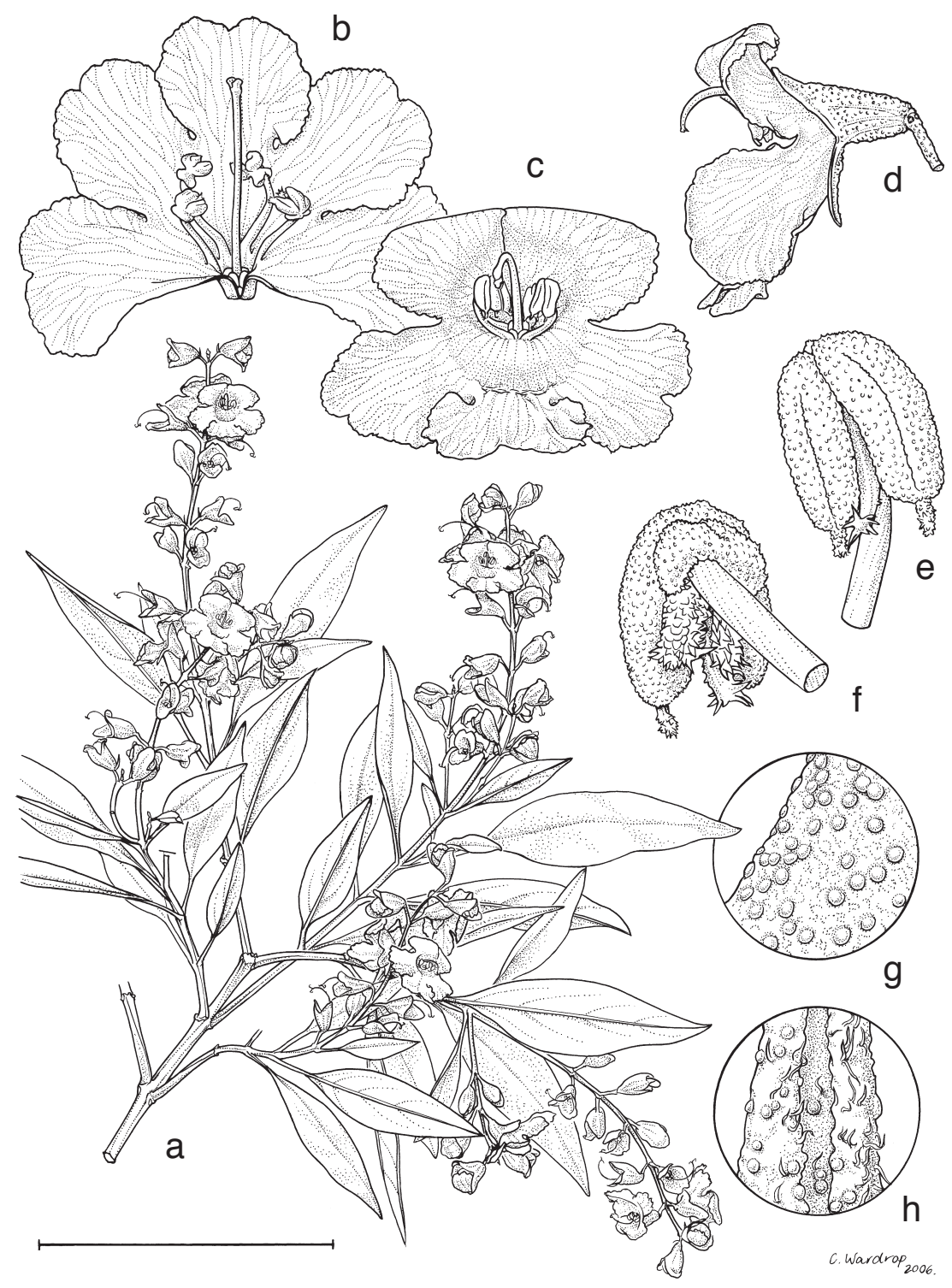

Fig. 1. Prostanthera petraea $\mathbf{a}$, branchlets showing leaves, flowers and developing fruits; $\mathbf{b}$, flower (ventral view), with adaxial lobe-pair dissected to show androecium and gynoecium; c, flower (ventral view) showing corolla, androecium and gynoecium; d, flower (side view) showing calyx, corolla, style and stigma; e, stamen (ventral view) showing connective and anther appendages; f, stamen (dorsal view) showing connective and anther appendages; $\mathbf{g}$, detail of adaxial surface of leaf showing hemispherical glands; $\mathbf{h}$, detail abaxial surface of petiole showing hairs and hemispherical glands (a-g from Conn $3670 \&$ Brown; h from Conn $3668 \&$ Brown; both NSW). Scale bar: $\mathrm{a}=55 \mathrm{~mm}, \mathrm{~b}-\mathrm{d}=15 \mathrm{~mm}$; e \& $\mathrm{f}=3 \mathrm{~mm}$; $\mathrm{g} \& \mathrm{~h}=20 \mathrm{~mm}$. Illustration by Catherine Wardrop. 
Selected specimens examined (17 seen): New South Wales: Northern Tablelands: Bald Rock National Park: Bungoona Walking Track, Conn 3670 \& Brown, 11 Oct 1992 (AD, BRI, MEL, NSW); Boorook State Forest: Bridge on Boorook Creek, Copeland 586, 22 Oct 1997 (NE, NSW); summit of Bald Rock, Jobson 5225 \& Mills, 25 Oct 1997 (BRI, NSW); Boonoo Boonoo National Park: 4 miles from Boonoo Boonoo Falls, Williams s.n., 19 Nov 1965 (BRI, NE, NSW).

Distribution: this species is restricted to the Boonoo Boonoo-Bald Rock area (northeast of Tenterfield), New South Wales. Since P. petraea is more or less restricted to areas that have not been subjected to fires, such as amongst large granite boulders and along water-courses, this intolerance to frequent bushfires may explain why it is not more widespread.

Habitat: Prostanthera petraea grows in Callitris-Eucalyptus woodland and Leptospermum novae-angliae heath with Philotheca myoporoides, Oxylobium arborescens, Phebalium ambiens, Styphelia and Leucopogon understorey. Growing amongst granite boulders in skeletal black peaty sand or shallow coarse sand.

Etymology: the specific epithet (viz. petraea) refers to the habitat of large granite boulders amongst which this species grows. The epithet also acknowledges the aboriginal place name 'Boonoo Boonoo' (which means 'large rocks'), one of the areas in which this species occurs.

Notes: the affinities of this species appear to be with Prostanthera lasianthos with both having similar shaped flowers and white corollas. However, $P$. lasianthos has a more elaborate, paniculate inflorescence (cf. botryoidal in $P$. petraea); corolla with markings on the inner surface (cf. P. petraea that almost always lacks corolla markings); and midgreen, more or less glossy leaves which are usually shortly toothed (cf. P. petraea which has pale olive-green, dull leaves with margin entire).

Conservation status: this species is probably adequately conserved within the Bald Rock National Park, Boonoo Boonoo National Park and the Boorook State Forest. However, it is likely to be a vulnerable species because of its very restricted distribution.

Prostanthera stenophylla B.J.Conn, sp. nov.

P. graniticae Maiden \& Betche affinis, a qua foliis angustis (1.5-2 mm. latis), indumento molli differt.

Holotype: New South Wales: Central Tablelands: Dunns Swamp area, Wollemi National Park, P.C. Jobson 4354, 28 Sep. 1996, (NSW 619013); isotypes: AD, B, BM, BRI, CANB, E, K, MEL, NSW 619015, NY, US.

Prostanthera species A sensu Conn, in Harden (ed.) Flora of New South Wales, vol. 3: 650 and fig. (1992); PlantNET (http://plantnet.rbgsyd.nsw.gov.au) (accessed March 2006) and images as 'Prostanthera sp. A sensu Conn (1992)'; 'Prostanthera rylstonii' sensu Nursery Trade (in use 2005), nom. nud.; Prostanthera sp. 'Rylstone' in Australian Plant Name Index (APNI) (http://www.anbg.gov.au/cpbr/databases/apni.html) (accessed June 2006).

Erect slender shrub, 1.5-2.5 m high. Branchlets terete, densely hairy (35-48 hairs/ $\mathrm{mm}^{2}$ ); hairs patent or slightly retrorse to antrorse, $0.1-0.2 \mathrm{~mm}$ long, straight to slightly curved, white; glands hemispherical, subsessile, moderately dense to sparse (on older branchlets) (10-36 glands $/ \mathrm{mm}^{2}$ ). Leaves dull green above, slightly paler below, strongly aromatic (when crushed); petiole very short, c. $0.5 \mathrm{~mm}$ long (often appearing absent), 


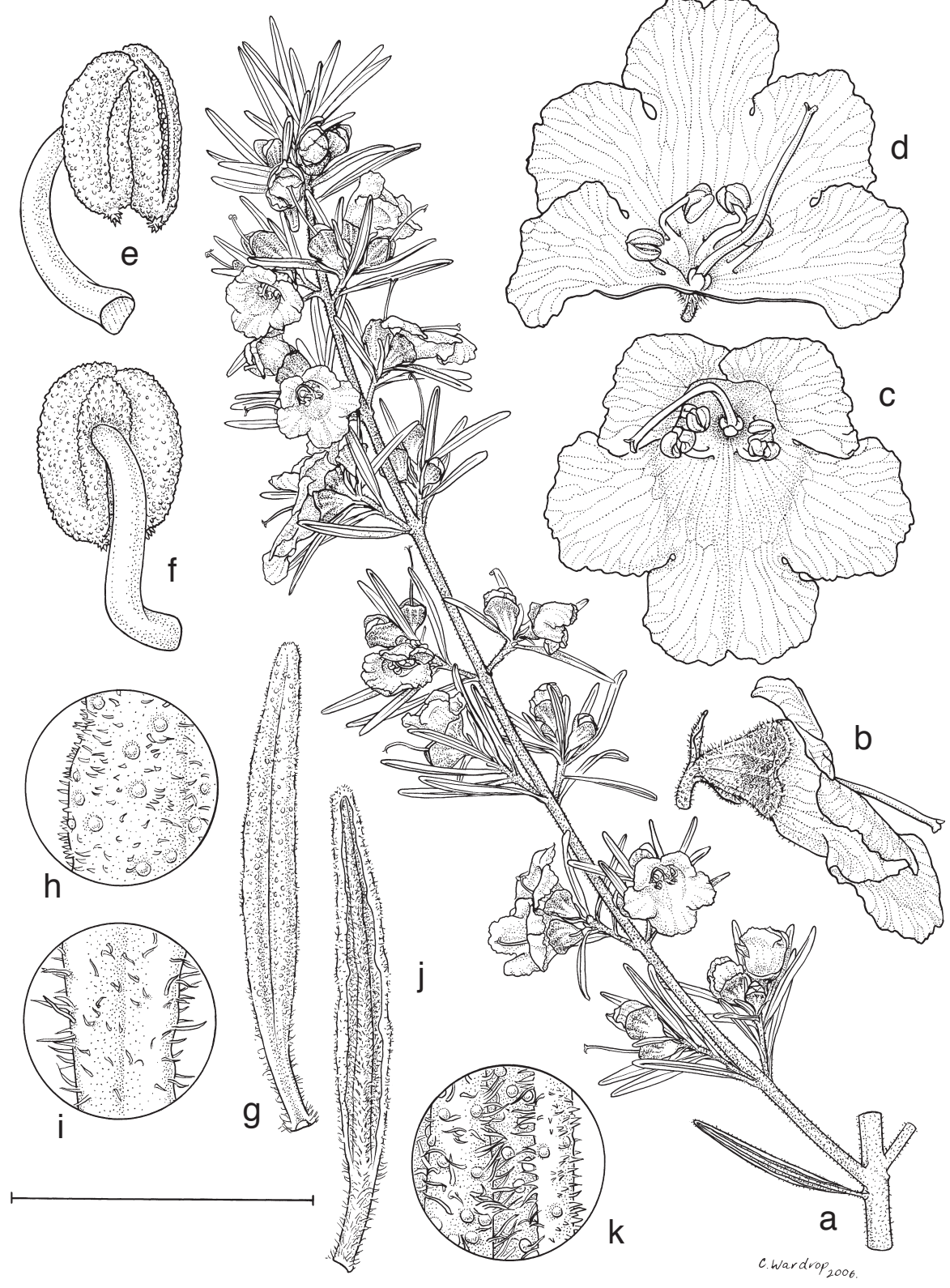

Fig. 2. Prostanthera stenophylla a, branchlets showing leaves and flowers; b, flower (side view) showing prophyll, calyx, corolla, style and stigma; c, flower (ventral view) showing corolla, androecium and gynoecium; $\mathbf{d}$, flower (ventral view), with adaxial lobe-pair dissected to show androecium and gynoecium; e, stamen (ventral view); f, stamen (dorsal view); g, leaf (adaxial view); $\mathbf{h}$, detail of adaxial surface of leaf showing hairs and hemispherical glands; $\mathbf{i}$, detail of abaxial surface of petiole showing hairs; $\mathbf{j}$, leaf (abaxial view); $\mathbf{k}$, detail of abaxial surface of leaf showing hairs and hemispherical glands (from Jobson 4354, NSW). Scale bar: a=30 mm, b \& c=12 mm; d=15 mm; e \& f=3 mm; g \& j=10 mm; h, i, k=2.1 mm. Illustration by Catherine Wardrop winner of the Margaret Flockton Award for 2006. 
\pm grading into base of lamina; lamina narrowly ovate to narrowly elliptic, appearing oblong to narrowly oblong because margin revolute to strongly recurved, 7-14 mm long, $1.5-2 \mathrm{~mm}$ wide (length to width ratio $5-7$, length of maximum width from base to total lamina length ratio 0.3-0.4), densely hairy, hairs c. $0.1 \mathrm{~mm}$ long, patent (abaxial surface), slightly antrorse (adaxial surface), densely glandular (as for branchlets); base attenuate; margin entire, strongly recurved such that only midvein of abaxial surface visible; apex obtuse; venation indistinct, midrib slightly raised on abaxial surface. Inflorescence a frondose racemiform conflorescence (on short side shoots), uniflorescence monadic; 4-6-flowered (per conflorescence). Podium 0.5-0.7 $\mathrm{mm}$ long, densely hairy and glandular. Prophylls \pm persistent, inserted just below the calyx $\left(\mathrm{a}_{1}\right.$ axis to anthopodium ratio c. 3), opposite, narrowly oblong to slightly narrow-elliptic to -obovate, $1.2-1.6 \mathrm{~mm}$ long, c. $0.4 \mathrm{~mm}$ wide (length to width ratio c. 4, length of maximum width from base to total lamina length ratio 0.5-0.6), densely hairy (hairs as for abaxial surface of leaf lamina), densely glandular; base attenuate; margin entire; apex obtuse; venation not visible. Calyx green basally, strongly maroon distally, especially on lobes; outer surface densely hairy throughout, slightly less dense distally, with hairs white, patent to slightly retrorse, c. $0.5 \mathrm{~mm}$ long, moderately to densely glandular; inner surface of tube glabrous, lobes densely hairy, with hairs c. $0.1 \mathrm{~mm}$ long, \pm patent; tube 2-2.8 $\mathrm{mm}$ long; abaxial lobe transversely broad-elliptic to very broadly ovate, $1.4-2.2 \mathrm{~mm}$ long, 2.5-3.8 mm wide at base (length to width ratio 0.4-0.8), apex rounded, very slightly irregular; adaxial lobe transversely ovate to transversely oblong, 1-2.5 $\mathrm{mm}$ long, 2.2-4 mm wide at base (length to width ratio 0.5-0.6), apex rounded to almost truncate (adaxial lobe length to abaxial lobe length ratio 1-1.3). Corolla 8-12 mm long, pale bluish mauve, lacking markings; outer surface glabrous basally, distally sparsely hairy (7-9 hairs $/ \mathrm{mm}^{2}$ ), hairs $0.6-1.2 \mathrm{~mm}$ long, \pm spreading, sparsely glandular on distal parts of tube and base of lobes ( $2-5$ glands/ $\left.\mathrm{mm}^{2}\right)$; inner surface glabrous; tube c. $4 \mathrm{~mm}$ long; abaxial median lobes transversely broad-spathulate, 4-5 mm long, 4.5-5 mm wide (length to width ratio 0.8-1), apex irregular and rounded, usually bilobed (sinus c. $0.4 \mathrm{~mm}$ long, c. $2.5 \mathrm{~mm}$ wide distally); lateral lobes oblong to slightly elliptic, 3-3.5 mm long, 3-3.8 mm wide (length to width ratio 0.8-1), apex rounded to slightly retuse, slightly irregular; adaxial median lobe-pair depressed ovate to very depressed ovate, $3.8-4.2 \mathrm{~mm}$ long, $8.5-10 \mathrm{~mm}$ wide (length to width ratio c, 0.4 ), apex rounded, irregular, bilobed (sinus $2.5-3 \mathrm{~mm}$ long, median margin of lobes usually touching or overlapping). Stamens inserted 2-2.5 mm above base of corolla; filaments 2-2.3 mm long; anthers 1-1.2 mm long, base of lobes glabrous or with a few narrowly triangular trichomes (up to $0.1 \mathrm{~mm}$ long), usually with small acumen basally, connective appendage absent or minute and indistinct, with a few narrowly triangular trichomes up to $0.1 \mathrm{~mm}$ long. Disc c. $0.2 \mathrm{~mm}$ long. Pistil 5.5-6 mm long; ovary cylindrical obovoid, $0.4-0.5 \mathrm{~mm}$ long, diameter at base $0.5-0.7 \mathrm{~mm}$, lobes 0.1-0.2 mm long; style 8.5-9.5 mm long; stigma lobes $0.8-1 \mathrm{~mm}$ long (unequal in length). Fruiting calyx not or only slightly enlarged. Mericarps $1-1.4 \mathrm{~mm}$ long, distally c. $1 \mathrm{~mm}$ extended beyond base of style, distal diameter $1.8-2 \mathrm{~mm}$; seeds ellipsoidcylindrical, c. $1 \mathrm{~mm}$ long, c. $0.5 \mathrm{~mm}$ diameter. Figure 2.

Flowering: throughout the year, but mostly in Spring. Fruiting: mostly late Spring to early Summer. 
Selected specimens examined (22 seen): New South Wales: Central Tablelands: Wollemi National Park: Althofer 2, pre-June 1952 (MEL); Althofer s.n., 1953 (NSW); Carrick 3240 \& 3242, 27 Oct 1972 (AD, NSW); Conn 823, 26 Aug 1980 (MEL); Ford 619, 19 Oct 1991 (NSW, SYD); Johnstone 823 \& Jobson, 16 Oct 1999 (NSW); Weston 2607, 29 Aug 2003 (NSW); Washington s.n., May 1998 (NSW). Locality uncertain: Southern Tablelands: Canberra district, Pryor s.n., Dec 1937 (NSW).

Distribution: the only confirmed populations of this species occur in the western parts of the Wollemi National Park, New South Wales. The herbarium collection by Lindsay D. Pryor from the imprecisely described 'Canberra District' is regarded as unlikely to be correct.

Habitat: this species occurs in sandy loamy soil, amongst sandstone outcrops ('pagodas') in dry sclerophyll forest dominated by Eucalyptus piperita, E. rossii and Callitris endlicheri.

Etymology: the specific epithet (viz. stenophylla) refers to the narrow leaves characteristic of this species.

Notes: this species is characterised by having leaves that are strongly aromatic, densely hairy, revolute to strongly recurved, hence appearing narrow. The flowers have anthers that either lack connective appendages or they are minute and indistinct. The affinities of this species are unclear, but it is morphologically similar to P. granitica, being readily distinguished from the latter by its relatively soft indumentum compared to the coarse, rough (to touch) hairs of $P$. granitica. Furthermore, although both species have revolute leaves, those of $P$. granitica are generally less strongly revolute and broader (2-5 mm wide) than those of P. stenophylla (1.5-2 mm wide). The margin of the leaf lamina appears to be usually entire, but occasionally, all the leaves of a plant (Althofer s.n.) or an occasional leaf, of a plant with otherwise entire leaves (Jobson 4354), is slightly or distinctly lobed to sub-crenate with lobes porrect (up to c. $0.4 \mathrm{~mm}$ long).

This species was recognized as an undescribed species by George W. Althofer in 1952 who quickly promoted this species as suitable for horticulture. Cuttings of P. stenophylla were broadly distributed amongst home-gardeners interested in the cultivation of Australian native plants. This species is now available from commercial plant nurseries under the unpublished name 'Prostanthera rylstonii'.

Conservation status: although this species occurs in the Wollemi National Park, it appears to have a very restricted distribution and so should, at least, be considered as vulnerable.

\section{Acknowledgments}

I thank the late George Althofer (then Wellington, N.S.W.) for informing me of the presence of both species and his brother, the late Peter Althofer (also from Wellington), who accompanied me on a field visit to the main population of Prostanthera stenophylla. I gratefully acknowledge advice on the Latin diagnoses provided by Dr Peter Wilson (NSW) and thank Catherine Wardrop (NSW) for preparing the detailed illustrations. 
Peter Jobson (NSW) kindly re-collected suitable type material of $P$. stenophylla. Elizabeth Brown (NSW) assisted with the collection of the type material of P. petraea. Additional herbarium collections held at AD, BRI, MEL and NE were examined during the taxonomic evaluation of these species. I thank the directors, curators and staff for allowing me access to these important collections.

\section{References}

Conn BJ (1984) A taxonomic revision of Prostanthera Labill. Section Klanderia (F.v. Muell.) Benth. (Labiatae). Journal of the Adelaide Botanic Gardens 6: 207-348.

Conn BJ (1992) Prostanthera. Pp. 646-662 in Harden GJ (ed.) Flora of New South Wales, vol. 3. (New South Wales University Press: Kensington)

Conn BJ (1995) Description of inflorescence axes in the genus Logania R.Br. (Loganiaceae). Kew Bulletin 50: 777-783.

Manuscript received 15 March 2006, accepted 27 June 2006 